\title{
Allergen and Ozone Exacerbate Serotonin- Induced Increases in Airway Smooth Muscle Contraction in a Model of Childhood Asthma
}

\author{
Brian D. Moore Dallas Hyde Lisa Miller Emily Wong Jessica Frelinger \\ Edward S. Schelegle \\ Department of Anatomy, Physiology and Cell Biology, School of Veterinary Medicine, and Respiratory Diseases \\ Unit, California National Primate Research Center, University of California - Davis, Davis, Calif., USA
}

\section{Key Words}

Air pollution $\cdot$ House dust mite allergen $\cdot$ Airway

hyperresponsiveness $\cdot$ Rhesus monkeys $\cdot$ Serotonin •

Childhood asthma

\begin{abstract}
Background: Serotonin (5-HT) modulates cholinergic neurotransmission and exacerbates airway smooth muscle (ASM) contraction in normal animal and nonasthmatic human tissue. Exposure to house dust mite allergen (HDMA) and ozone $\left(\mathrm{O}_{3}\right)$ leads to airway hyperreactivity and 5-HT-positive cells in the airway epithelium of infant rhesus monkeys. Research shows that concomitant exposure in allergic animals has an additive effect on airway hyperreactivity. Objectives: In this study, the hypothesis is that the exposure of allergic infant rhesus monkeys to $\mathrm{HDMA}, \mathrm{O}_{3}$ and in combination, acting through 5-HT receptors, enhances 5-HT modulation of postganglionic cholinergic ASM contraction. Methods: Twenty-four HDMA-sensitized infant monkeys were split into 4 groups at the age of 1 month, and were exposed to filtered air (FA), $\mathrm{HDMA}, \mathrm{O}_{3}$ or in combination $\left(\mathrm{HDMA}+\mathrm{O}_{3}\right)$. At the age of 6 months, airway rings were harvested and postganglionic, and parasympathetic-mediated ASM contraction was evaluated using electrical-field stimulation
\end{abstract}

\section{KARGER}

Fax +4161306 1234

E-Mail karger@karger.ch

www.karger.com
(C) 2012 S. Karger AG, Basel

0025-7931/12/0836-0529\$38.00/0

Accessible online at:

www.karger.com/res
(EFS). Results: 5 -HT exacerbated the EFS response within all exposure groups, but had no effect in the FA group. $5-\mathrm{HT}_{2}$, $5-\mathrm{HT}_{3}$ and $5-\mathrm{HT}_{4}$ receptor agonists exacerbated the response. 5-HT concentration-response curves performed after incubation with specific receptor antagonists confirmed the involvement of $5-\mathrm{HT}_{2}, 5-\mathrm{HT}_{3}$ and $5-\mathrm{HT}_{4}$ receptors. Conversely, a $5-\mathrm{HT}_{1}$ receptor agonist attenuated the tension across all groups during EFS, and in ASM contracted via exogenous acetylcholine. Conclusions: $\mathrm{HDMA}, \mathrm{O}_{3}$ and $\mathrm{HDMA}+\mathrm{O}_{3}$ exposure in a model of childhood allergic asthma enhances 5-HT exacerbation of EFS-induced ASM contraction through $5-\mathrm{HT}_{2}, 5-\mathrm{HT}_{3}$ and $5-\mathrm{HT}_{4}$ receptors. A nonneurogenic inhibitory pathway exists, unaffected by exposure, mediated by $5-\mathrm{HT}_{1}$ receptors located on ASM.

Copyright $\odot 2012$ S. Karger AG, Basel

\section{Introduction}

In 2009, approximately 7.1 million children were diagnosed with asthma in the USA. Children's asthma-related hospital visits have doubled since 1980 and asthma is responsible for 14 million school days missed annually [13]. Annual asthma-related costs in the USA approach 13 billion dollars [4]. Although the etiology of asthma is 
multifaceted, two environmental factors are linked to its development and exacerbation. The risk of developing asthma increases in individuals allergic to house dust mite allergen (HDMA), and $85 \%$ of atopic asthmatics exhibit sensitivity to HDMA [5, 6]. Asthmatics exposed to high-ambient ozone $\left(\mathrm{O}_{3}\right)$ concentrations have lower quality of life scores, decreased lung function and exhibit allergic inflammation [7]. Chronic exposure to higher levels of $\mathrm{O}_{3}$ is associated with asthma development in active children [8]. In the latest State of the Air report compiled by the American Lung Association, almost half of the citizens of the USA, over 148 million people, live in areas with unhealthy levels of $\mathrm{O}_{3}$ [9].

Due to extensive postnatal maturation of the lung, exposure to HDMA and/or $\mathrm{O}_{3}$ in early childhood may induce changes resulting in reduced lung function in adulthood. Current levels of air pollution have been shown to have chronic, adverse effects on lung function development in children [10]. Early postnatal exposure of monkeys to HDMA and $\mathrm{O}_{3}$ results in airway hyperresponsiveness (AHR) that is associated with altered structural, neural and immunological development of the lung [1115]. These changes in airway development persist after exposure is discontinued [16]. Previous research also suggests that $\mathrm{O}_{3}$ can amplify the allergic, functional and structural remodeling effects of HDMA sensitization and inhalation [12]. Although HDMA and $\mathrm{O}_{3}$ exposure are associated with asthma-related symptoms, the mechanisms responsible for their clinical manifestation have not been elucidated.

Serotonin (5-HT) is found primarily in the gastrointestinal tract, CNS and platelets, exerting its effects through 14 distinct receptors whose distribution and specificity dictate the effect of $5-\mathrm{HT}$ on the target tissue [17]. 5-HT can modulate cholinergic signaling by activating presynaptic heteroreceptors on cholinergic nerve terminals, facilitating an increase in the release of acetylcholine (ACh) during excitation $[17,18]$. In airway tissue obtained from healthy, nonasthmatic animals and in a limited number of human thoracotomy specimens, 5-HT enhances cholinergic-mediated airway smooth muscle (ASM) contraction [19-23]. Whole animal studies have also verified its ability to increase airway resistance [2429]. The episodic exposure of infant rhesus monkeys to HDMA and $\mathrm{O}_{3}$ results in 5-HT-positive cells within the airway epithelia that persist for at least 6 months [13]. Asthmatics have higher 5-HT plasma levels than controls and these are inversely correlated with lung function [30, 31]. In a year-long double-blind crossover study of symptomatic asthmatics, treatment with a medication that lowers free plasma 5-HT decreased the severity of asthma symptoms and led to a significant increase in pulmonary function [32]. These studies indicate that increases in the presence of 5-HT, or hypersensitivity of the sensory nerves, parasympathetic ganglia or ASM to 5-HT could contribute to the development of AHR in asthma. However, to date, no study has examined the role of 5-HT and its receptors in a model of asthma [20-22, 33, 34].

In this study, the hypothesis is that the exposure of allergic infant rhesus monkeys to $\mathrm{HDMA}, \mathrm{O}_{3}$ and in combination ( $\mathrm{HDMA}+\mathrm{O}_{3}$ ), acting through $5-\mathrm{HT}$ receptors, enhances the 5-HT modulation of postganglionic cholinergic ASM contraction. Rhesus monkeys were used because they have similar lung cellular morphology, airway architecture and immunology to humans and they undergo a similar extensive period of postnatal development [35-39]. In addition to possessing all of the components of the intrapulmonary conducting airways that are altered in human asthmatics, rhesus monkeys display a similar progression of asthma pathophysiology and symptoms [40,41]. The sensitization protocol utilized in this study has been shown to induce the functional, immunological, histological and clinical characteristics that are used to diagnose allergic asthma [41].

\section{Methods}

Care and housing of animals complied with the provisions of the Institute of Laboratory Animal Resources and conformed to the practices established by the American Association for Accreditation of Laboratory Animal Care (AAALAC). Procedures were approved by the UC Davis Institutional Animal Care and Use Committee, and followed the Guide to the Care and Use of Laboratory Animals [42]. UC Davis and the California National Primate Research Center are accredited by AAALAC.

\section{General Protocol}

Twenty-four captive-born rhesus monkeys (Macaca mulatta) were used in this study. Monkeys that were 30 days old were randomly assigned to 1 of 4 groups ( $n=6 /$ group) depending on the type of exposure: filtered air (FA), $\mathrm{HDMA}, \mathrm{O}_{3}$ or $\mathrm{HDMA}+\mathrm{O}_{3}$. All animals were sensitized to HDMA and each group was exposed to 11 episodes of FA, HDMA aerosol, $\mathrm{O}_{3}$ or $\mathrm{HDMA}+\mathrm{O}_{3}$ as previously described [41, 43] (fig. 1). Exposures had a total HDMA mass-concentration averaging $6.46+0.04 \mathrm{mg} / \mathrm{m}^{3}$ and a mean $\mathrm{O}_{3}$ concentration of $0.5+0.004 \mathrm{ppm}$. Monkeys were euthanized with intravenous sodium pentobarbital $(15 \mathrm{ml} / \mathrm{kg})$. A distal tracheal portion was harvested and placed in modified Kreb's solution ( $\mathrm{NaCl} 118 \mathrm{~mm}, \mathrm{KCl} 5.4 \mathrm{~mm}, \mathrm{NAHCO}_{3} 25 \mathrm{~mm}$, dextrose $11.1 \mathrm{~mm}$, $\mathrm{Na}_{2} \mathrm{HPO}_{4} 1 \mathrm{~mm}, \mathrm{MgSO}_{4} 1.2 \mathrm{~mm}$ and $\mathrm{CaCl} 1.9 \mathrm{~mm}$ ).

Allergen Sensitization Protocol and Procedures

At weeks 1, 3 and 7, animals were given a 1.0 -cc injection of Der p $1(0.5 \mu \mathrm{g}) /$ Der p $2(0.25 \mu \mathrm{g})$ in $10 \mathrm{mg}$ alum placed in the 


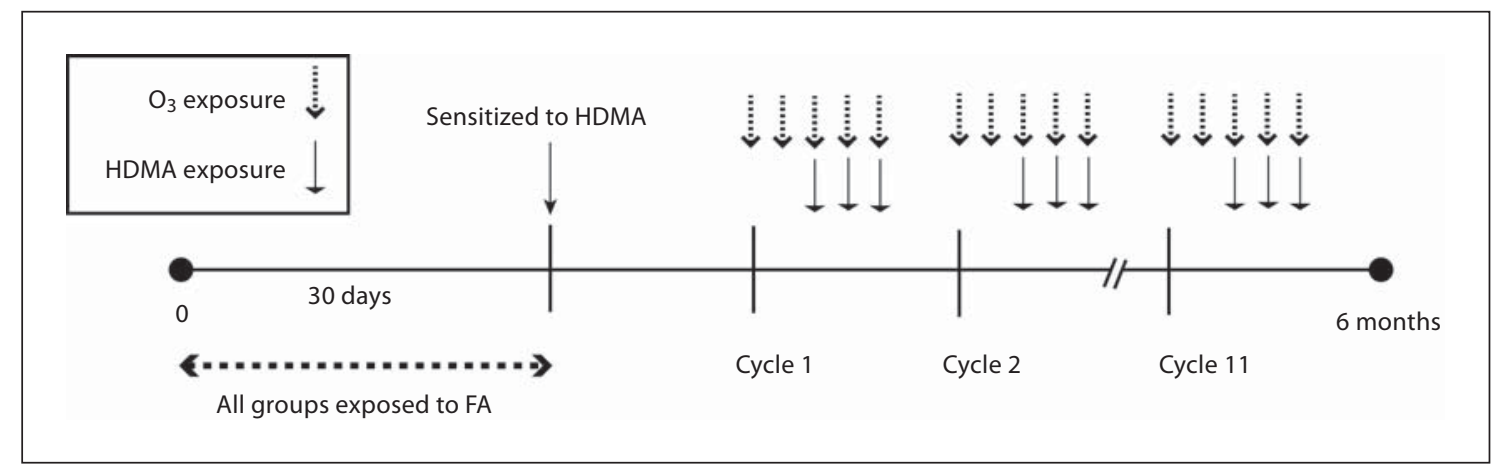

Fig. 1. Timeline of exposure protocol. All monkeys were sensitized to HDMA at 30 days of age and exposed to eleven 14-day cycles of FA, $\mathrm{HDMA}, \mathrm{O}_{3}$ or $\mathrm{HDMA}+\mathrm{O}_{3} . \mathrm{O}_{3}$ was delivered on days $1-5$ of the cycle. HDMA was delivered on days $3-5$ of the cycle.

upper back SQ. During week 1, animals were given a 0.1-cc injection of Infanrix in the thigh IM. At weeks 2, 4 and 8, HDMA intranasal consisting of $25 \mu \mathrm{g}$ total Der $\mathrm{p}$ (whole extract) in PBS was injected into each nostril. At week 15, the animals received a 1.0cc injection of $1 \mu \mathrm{g}$ Der p $1+0.5 \mu \mathrm{g}$ Der $\mathrm{p} 2$ in $10 \mathrm{mg}$ alum in the upper back SQ.

\section{Intradermal Skin Testing}

Skin tests were done at 7, 12 and 22 weeks of age. Monkeys were anesthetized with ketamine hydrochloride and hair was clipped from an area of the thorax. Three intradermal injections $(0.1 \mathrm{ml})$ of PBS containing HDMA $(1: 1,000 \mathrm{w} / \mathrm{v})$, histamine $(1: 1,000)$ or diluent alone were made at the site. Injection sites were observed for $30 \mathrm{~min}$ and wheal diameters were measured after $20 \mathrm{~min}$. A skin test was positive if the diameter of the wheal that formed in response to HDMA was greater than or equal to a length halfway between the diameters of the wheal produced by the diluent (negative control) and histamine (positive control) [12, 41].

\section{Airway Responsiveness Testing}

The 24 monkeys whose tissue was harvested for electrical-field stimulation (EFS) analysis were members of a larger cohort of sensitized animals who underwent airway responsiveness testing at 6 months. Airway resistance was measured during a histamine challenge and results were expressed as the concentration of histamine resulting in a $200 \%$ increase in airway resistance from baseline $\left(E C 200 R_{a w}\right)$. Methods followed those described in detail by Schelegle [41]. EC200R $\mathrm{R}_{\mathrm{aw}}$ results include data from the entire cohort of sensitized and exposed monkeys.

\section{Electrical Field Stimulation}

Airway rings were suspended between platinum wire electrodes and placed in tissue baths (Myobath, WPI Inc., Sarasota, Fla., USA) containing modified Kreb's solution with indomethacin $(10 \mu \mathrm{M})$, phentolamine $(0.1 \mu \mathrm{M})$, ICI $118,551(0.1 \mu \mathrm{M})$ and hexamethonium $(1 \mu \mathrm{M})$ to isolate cholinergic signaling at postganglionic nerves. Tissue was equilibrated under $1 \mathrm{~g}$ of tension for $90 \mathrm{~min}$. Tension was measured via Fort $10 \mathrm{~g}$ transducers (WPI Inc., Sarasota, Fla., USA) and recorded with Powerlab Chart 5.1 software (ADInstruments, Colorado Springs, Colo., USA). During equilibration, tissue was incubated with capsaicin $(10 \mu \mathrm{M})$ for 30 min to deplete the sensory nerves of endogenous tachykinins. Tissue baths were maintained at $37^{\circ} \mathrm{C}$ and continuously bubbled with $5 \% \mathrm{CO}_{2}$ in $\mathrm{O}_{2}$. Monophasic square-wave impulses at a voltage of $50 \mathrm{~V}$ and a frequency of $4 \mathrm{~Hz}$ with duration of $0.5 \mathrm{~ms}$ were delivered for $30 \mathrm{~s}$ every $4 \mathrm{~min}$ until 3 consecutive stable responses were obtained. Pulses were induced via three S88 Stimulators (Grass Technologies, West Warwick, R.I., USA).

\section{Concluding Experiments}

At the conclusion of the protocol, airway rings were exposed to $10 \mathrm{mM} \mathrm{ACh}$. The tension produced during this trial was compared to the tension achieved with $10 \mathrm{~mm}$ ACh during the initial ACh concentration-response curve. To ensure that the contractions elicited were due to the activation of muscarinic receptors located directly on the ASM, the EFS response prior to and following the addition of atropine $(1 \mu \mathrm{M})$ was evaluated. To verify that the responses were neurogenic, the tissue was incubated in $3 \mu \mathrm{M}$ tetrodotoxin prior to EFS. All drugs were purchased from Sigma-Aldrich Company (St. Louis, Mo., USA).

\section{Baseline Response Testing}

Two ACh concentration-response curves were performed: 1 control and 1 preincubated with $10 \mu \mathrm{M} 5$-HT. A voltage-response curve and a frequency-response curve were performed on each tracheal ring to evaluate any baseline differences between groups during EFS-induced contraction.

\section{5-HT and Agonist Concentration-Response}

Six rings from each animal were utilized to perform concurrent concentration-response curves with 5-HT or 1 of 45-HT subtype receptor agonists during EFS-induced ASM contractions (table 1). The direct effect of drug addition on ASM tension prior to EFS at each concentration was recorded. If 5-HT or agonist addition elicited a significant shift in baseline tension prior to EFS, the EFS data was excluded from analysis. Due to an unbalanced and reduced number of observations remaining after the addition of $100 \mu \mathrm{M} 5-\mathrm{HT}$ (after baseline shift exclusion), only the $5-\mathrm{HT}_{1}$ receptor agonist had data reportable at this concentration. 
Table 1. Summary of agonists with concentration range and references

\begin{tabular}{llll}
\hline Drug & Receptor & $\begin{array}{l}\text { Concentration } \\
\text { range }(\mu \mathrm{M})\end{array}$ & $\begin{array}{l}\text { Reference } \\
\text { number }\end{array}$ \\
\hline 8-OH-DPAT & $\begin{array}{l}\text { 5-HT } \\
\text { affinity } \text { 5-Hith high }\end{array}$ & $1,10,100$ & $44-46$ \\
$\begin{array}{l}\text { 2-Methylserotonin } \\
\text { 2-methylserotonin }\end{array}$ & $5-\mathrm{HT}_{2}$ & 1,10 & $47-49$ \\
ML 10302 & $5-\mathrm{HT}_{3}$ & 1,10 & $49-52$ \\
& & 1,10 & $53-55$ \\
\hline
\end{tabular}

Table 2. Summary of antagonists with concentration range and references

\begin{tabular}{llll}
\hline Drug & Receptor & $\begin{array}{l}\text { Concentration } \\
\text { range }(\mu \mathrm{M})\end{array}$ & $\begin{array}{l}\text { Reference } \\
\text { number }\end{array}$ \\
\hline Ketanserin & $5-\mathrm{HT}_{2}$ & $1,10,100$ & 56,57 \\
$\begin{array}{l}\text { Ondansetron } \\
\text { GR 113808 }\end{array}$ & $5-\mathrm{HT}_{3}$ & $1,10,100$ & 58,59 \\
& $5-\mathrm{HT}_{4}$ & $1,10,100$ & $60-62$ \\
\hline
\end{tabular}

\section{Antagonist Concentration-Response}

5 -HT concentration-response curves were performed in the presence of 3 concentrations of each 5-HT subtype receptor antagonist (table 2).

\section{Direct Effect of 8-OH-DPAT}

$100 \mu \mathrm{M}$ ACh was added to each tissue bath to induce an increase in tension. Once tension stabilized, 10 and $100 \mu \mathrm{M} 8-\mathrm{OH}-$ DPAT were added to separate baths. The remaining baths functioned as controls. Changes in tension following the addition of 8-OH-DPAT were monitored for $10 \mathrm{~min}$.

\section{Statistical Analysis}

Results are expressed as mean \pm standard error of the mean. Airway responsiveness data was analyzed using a 1-way ANOVA. Comparison of group means was done with Tukey post hoc testing. All contractile responses were measured as the difference between the resting tension and the peak tension developed. $\mathrm{EC}_{50}$ values were derived from the $\mathrm{ACh}$ concentration-response curves and exposure groups were compared to the FA control using a mixed model ANOVA with Dunnett's criterion. 5-HT, agonist and antagonist concentration-response trials were compared using a repeated-measures (concentration) ANOVA. The effects of concentration, exposure group and concentration $\times$ exposure group were evaluated. Tukey post hoc testing was utilized to identify the source of significance between the means of the subgroups. During antagonist concentration-response curves, the baseline tension was adjusted by subtracting the control EFS response from the EFS response after incubation with the antagonist. When evaluating the direct effect of 8-OH-DPAT on tissue precontracted with $100 \mu \mathrm{M}$ ACh, each tissue served as its own control, so a 2-sample paired t test design was employed. The $\alpha$ level was set at 0.05 for all experiments, and if multiple post hoc tests were performed, significance was based on the adjusted $\mathrm{p}$ value.

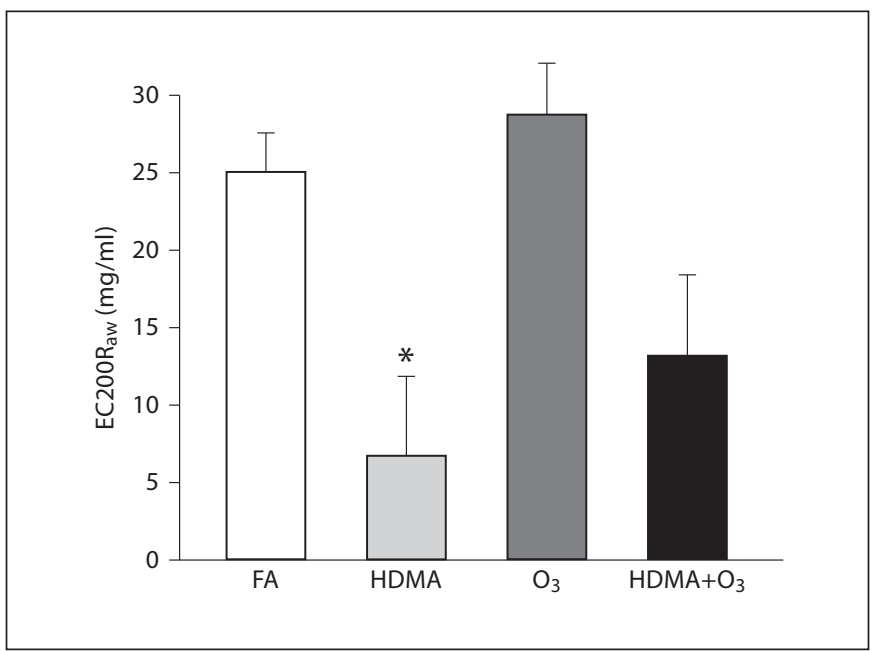

Fig. 2. Airway responsiveness testing. EC200R $\mathrm{R}_{\mathrm{aw}}$ (effective concentration inducing a $200 \%$ increase in airway resistance from baseline) across groups during airway challenge with histamine. * Significant decrease in EC200R $\mathrm{R}_{\mathrm{aw}}$ compared to FA. Values are means \pm SE. FA $n=24$, HDMA $n=6, O_{3} n=9, \mathrm{HDMA}+\mathrm{O}_{3} \mathrm{n}=$ $7(\mathrm{p}=0.05)$.

\section{Results}

\section{Airway Responsiveness Testing}

During histamine challenge, HDMA-exposed animals showed a significant decrease in EC200R $\mathrm{R}_{\mathrm{aw}}$ when compared to FA controls, indicating a hyperresponsive airway $(6.77+5.07 \mathrm{mg} / \mathrm{ml}$ vs. $25.05+2.54 \mathrm{mg} / \mathrm{ml})$. The $\mathrm{HDMA}+\mathrm{O}_{3}$ group showed a trend towards a reduced $\mathrm{EC}^{2} 20 \mathrm{R}_{\mathrm{aw}}$, but this reduction did not reach a level of significance $(13.18+5.19 \mathrm{mg} / \mathrm{ml})$. The EC200R $\mathrm{R}_{\mathrm{aw}}$ for the $\mathrm{O}_{3}$ group was $28.72 \pm 3.33 \mathrm{mg} / \mathrm{ml}$ (fig. 2).

\section{ACh Concentration-Response Curves}

The control ACh concentration-response curves were compared to the ACh concentration-response curves preincubated with $10 \mu \mathrm{M} 5-\mathrm{HT}$. The $\mathrm{EC}_{50}$ of the $5-\mathrm{HT}$ preincubated ACh concentration-response curve was significantly greater than that of the control curve ( $\mathrm{p}=$ 0.0203 ), indicating that preincubation with $10 \mu \mathrm{M} 5-\mathrm{HT}$ reduced the responsiveness of the ASM to exogenous $\mathrm{ACh}$ (fig. 3b). There was a significant increase in the $\mathrm{EC}_{50}$ of the $\mathrm{O}_{3}$ group when compared to the FA control $(\mathrm{p}=$ $0.024)$.

\section{Voltage-Response Curves}

There was no significant difference between any of the exposure groups and the FA control. 
Fig. 3. a $\mathrm{ACh}$ concentration-response curves with and without preincubation with $10 \mu \mathrm{M} 5$-HT, all groups combined. * Tension increase induced by $0.1 \mu \mathrm{M}$ ACh is significantly less in the tissue preincubated with $10 \mu \mathrm{M} 5$-HT. b EC 50 values derived from $\mathrm{ACh}$ concentration-response curves. ${ }^{*} \mathrm{EC}_{50}$ for tissue preincubated with $10 \mu \mathrm{M} 5$-HT is significantly greater. Values are means $\pm \mathrm{SE}, \mathrm{n}=6(\mathrm{p}<0.05)$.

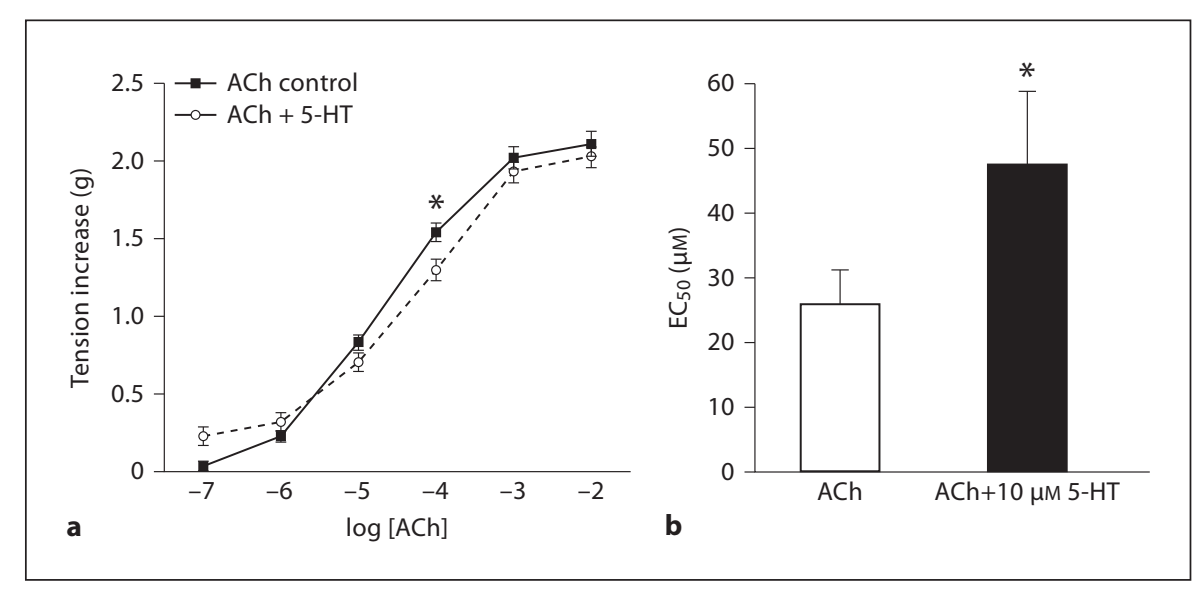

\section{Frequency-Response Curves}

There was no significant difference between any of the exposure groups and the FA control.

\section{5-HT Concentration-Response Curves with EFS}

The FA control group showed no within-group effect with the cumulative addition of 5-HT during EFS. The $\mathrm{HDMA}, \mathrm{O}_{3}$ and $\mathrm{HDMA}+\mathrm{O}_{3}$ groups showed a significant within-group effect of 5-HT. At $10 \mu \mathrm{M}$ 5-HT, EFS-induced tension increased by $56 \%$ in the FA group, whereas the tension of the combined-exposure groups increased by $176 \%$ over the EFS control (HDMA $=185 \%, \mathrm{p}<0.060 ; \mathrm{O}_{3}=$ $206 \%, \mathrm{p}<0.002 ; \mathrm{HDMA}^{2} \mathrm{O}_{3}=154 \%, \mathrm{p}<0.003$ ) (fig. 4).

\section{Agonist Concentration-Response Curves with EFS}

$5-\mathrm{HT}_{1}$ Receptor

There was a significant, concentration-dependent effect showing a decrease in EFS-induced muscle tension in all 3 exposure groups and the FA control with the addition of the $5-\mathrm{HT}_{1}$ receptor agonist $(\mathrm{p}<0.0001)$. At 100 $\mu \mathrm{M}$, the tension response to EFS was almost abolished (average response at $100 \mu \mathrm{M}$ of all 4 groups was 3\% of control). There were no between-group differences at any concentration and the FA group response was similar to that of the exposure groups, indicating that exposure had no effect (fig. 5a). The $5-\mathrm{HT}_{1}$ receptor agonist was the only agonist that produced an inhibitory effect on EFSinduced ASM contraction.

\section{5- $\mathrm{HT}_{2}$ Receptor}

Activation of $5-\mathrm{HT}_{2}$ receptors significantly increased muscle tension at 1 and $10 \mu \mathrm{M}$ in the HDMA group $(\mathrm{p}=$ 0.0002 ), with EFS at $1 \mu \mathrm{M}$ producing a $45 \%$ increase and $10 \mu \mathrm{M}$ producing a $102 \%$ increase over the control (fig. $5 \mathrm{~b}$ ).

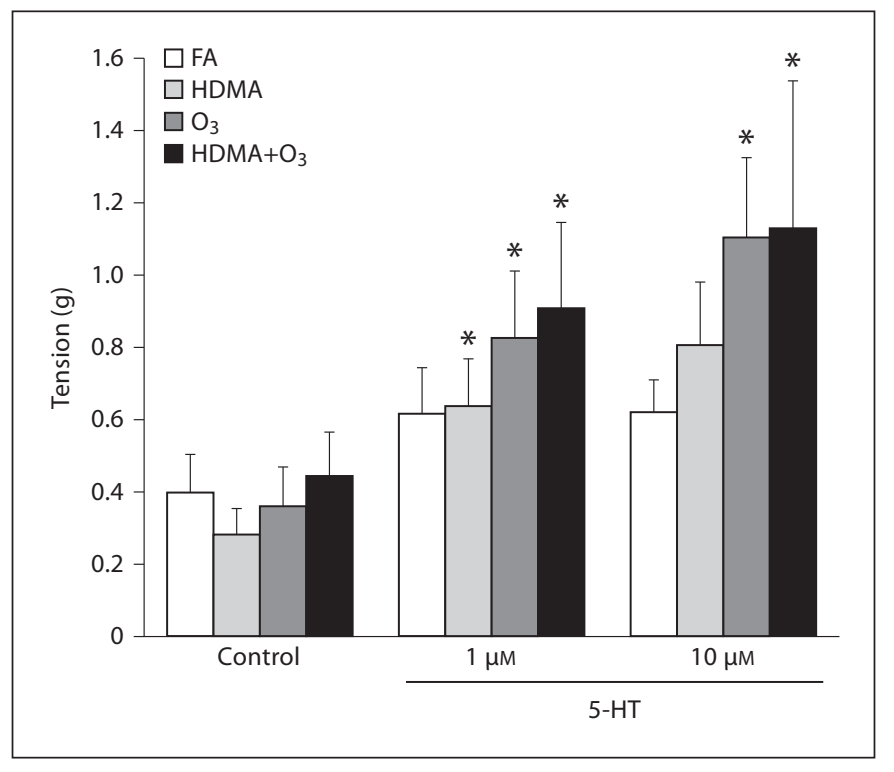

Fig. 4. 5-HT concentration response; tension response to EFS. * Tension increase greater than within group control response. FA group showed no significant within-group increase in tension. All 3 exposure groups showed a significant within-group increase in tension production. Values are means $\pm S E, n=6(p<0.05)$.

\section{$5-\mathrm{HT}_{3}$ Receptor}

$10 \mu \mathrm{M}$ of the $5-\mathrm{HT}_{3}$ receptor agonist significantly increased the EFS tension response in all 3 exposure groups (HDMA, $\mathrm{p}<0.012 ; \mathrm{O}_{3}, \mathrm{p}=0.007 ; \mathrm{HDMA}_{3}, \mathrm{p}<0.017$ ) (fig. 5c).

\section{5- $\mathrm{HT}_{4}$ Receptor}

In the $\mathrm{O}_{3}$ group, a significant increase in EFS-induced tension was seen at $1 \mu \mathrm{M}(\mathrm{p}=0.041)$. HDMA exposure 


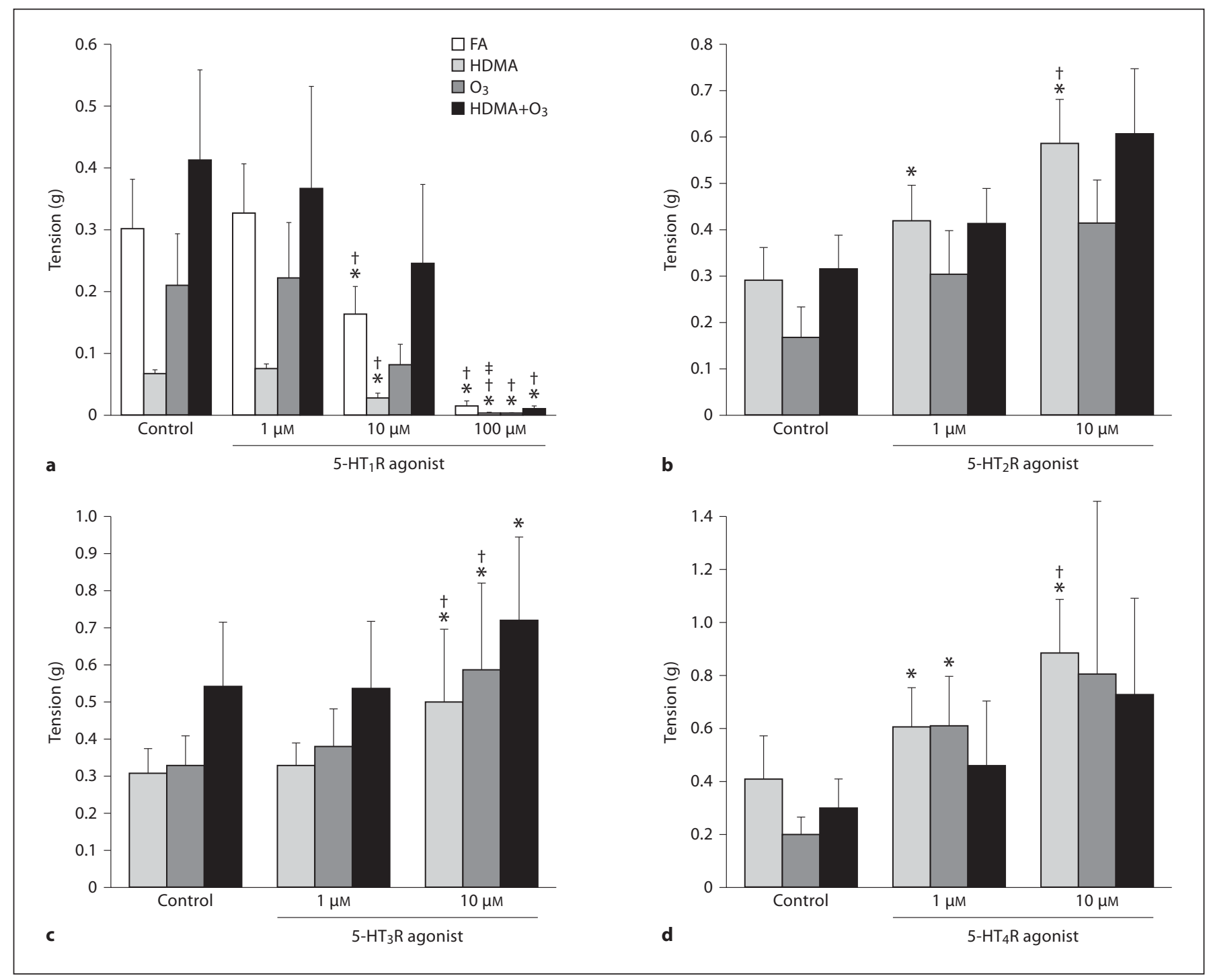

Fig. 5. Agonist concentration response; tension response to EFS. a 5- $\mathrm{HT}_{1}$ receptor $\left(5-\mathrm{HT}_{1} \mathrm{R}\right)$ agonist, $8-\mathrm{OH}-$ DPAT. b $5-\mathrm{HT}_{2} \mathrm{R}$ agonist, $\alpha$-methylserotonin. c $5-\mathrm{HT}_{3} \mathrm{R}$ agonist, 2 -methylserotonin. $\mathbf{d} 5-\mathrm{HT}_{4} \mathrm{R}$ agonist, ML 10302. * Tension is significantly different than within-group control. ${ }^{\dagger}$ Tension is significantly different than within-group $1-\mu \mathrm{M}$ response. ${ }^{\ddagger}$ Tension is significantly different than within-group 10- $\mu \mathrm{M}$ response. ${ }^{*}$ Values are means $\pm \mathrm{SE}, \mathrm{n}=6(\mathrm{p}<0.05)$.

significantly elevated tension at $1 \mu \mathrm{M}(\mathrm{p}=0.0001)$ and 10 $\mu \mathrm{M}(\mathrm{p}<0.0001)$ (fig. 5d).

\section{Antagonist Concentration-Response Curves}

To further evaluate the role of the 5-HT subtype receptors that the agonist trials indicated as contributors to the 5-HT-induced exacerbation of the EFS response, 5-HT concentration-response curves were conducted in the presence of increasing concentrations of 5-HT receptor antagonists.
Ketanserin (5- $\mathrm{HT}_{2}$ Receptor Antagonist)

HDMA-exposed tissue preincubated with 10 and 100 $\mu \mathrm{M}$ ketanserin significantly attenuated the EFS response at all 5-HT concentrations (fig. 6).

\section{Ondansetron (5- $\mathrm{HT}_{3}$ Receptor Antagonist)}

HDMA-exposed airway rings preincubated with 1,10 and $100 \mu \mathrm{M}$ ondansetron significantly attenuated the EFS response at 10 and $100 \mu \mathrm{M} 5$-HT. The tissue preincubated with 10 and $100 \mu \mathrm{M}$ ondansetron significantly re- 
Table 3. Summary of p values for antagonist concentration-response curves

\begin{tabular}{|c|c|c|c|c|c|c|c|c|c|c|}
\hline \multirow[t]{3}{*}{ Group } & \multirow[t]{3}{*}[5-\mathrm{HT}]{} & \multicolumn{9}{|l|}{ [ANT] } \\
\hline & & \multicolumn{3}{|c|}{ 5- $\mathrm{HT}_{2}$ receptor } & \multicolumn{3}{|c|}{ 5- $\mathrm{HT}_{3}$ receptor } & \multicolumn{3}{|c|}{$\underline{5-\mathrm{HT}_{4}}$ receptor } \\
\hline & & $1 \mu \mathrm{M}$ & $10 \mu \mathrm{M}$ & $100 \mu \mathrm{M}$ & $1 \mu \mathrm{M}$ & $10 \mu \mathrm{M}$ & $100 \mu \mathrm{M}$ & $1 \mu \mathrm{M}$ & $10 \mu \mathrm{M}$ & $100 \mu \mathrm{M}$ \\
\hline \multirow[t]{3}{*}{ HDMA } & $1 \mu \mathrm{M}$ & 0.8170 & 0.0376 & 0.0003 & 0.0133 & 0.8530 & $<0.0001$ & 0.0607 & 0.1203 & 0.0452 \\
\hline & $10 \mu \mathrm{M}$ & 0.6689 & 0.0014 & $<0.0001$ & 0.0042 & 0.0041 & $<0.0001$ & 0.0092 & 0.0096 & $<0.0001$ \\
\hline & $100 \mu \mathrm{M}$ & 0.7013 & 0.0012 & $<0.0010$ & 0.0498 & 0.0001 & $<0.0001$ & 0.0416 & 0.0066 & $<0.0001$ \\
\hline \multirow[t]{3}{*}{$\mathrm{O}_{3}$} & $1 \mu \mathrm{M}$ & & & & 0.9297 & 1.0000 & 0.0099 & 0.9164 & 0.9997 & 1.0000 \\
\hline & $10 \mu \mathrm{M}$ & & & & 0.1915 & 0.3656 & 0.0001 & 0.4808 & 0.7104 & $\mathbf{0 . 0 3 0 7}$ \\
\hline & $100 \mu \mathrm{M}$ & & & & 0.1024 & 0.0337 & $<0.0001$ & 0.6382 & 0.5070 & $<0.0001$ \\
\hline \multirow[t]{3}{*}{$\mathrm{HDMA}+\mathrm{O}_{3}$} & $1 \mu \mathrm{M}$ & & & & 0.9958 & 0.9999 & 0.4714 & & & \\
\hline & $10 \mu \mathrm{M}$ & & & & 0.4401 & 0.7666 & 0.0084 & & & \\
\hline & $100 \mu \mathrm{M}$ & & & & 0.4630 & 0.6431 & 0.0021 & & & \\
\hline
\end{tabular}

Adjusted $\mathrm{p}$ values for 5-HT concentration-response curves preincubated with 5-HT receptor subtype antagonists. $\mathrm{p}$ values represent comparison to response at the same 5-HT concentration in the control (no antagonist) curve.

Bold-type values indicate significance at $\alpha=0.05$.

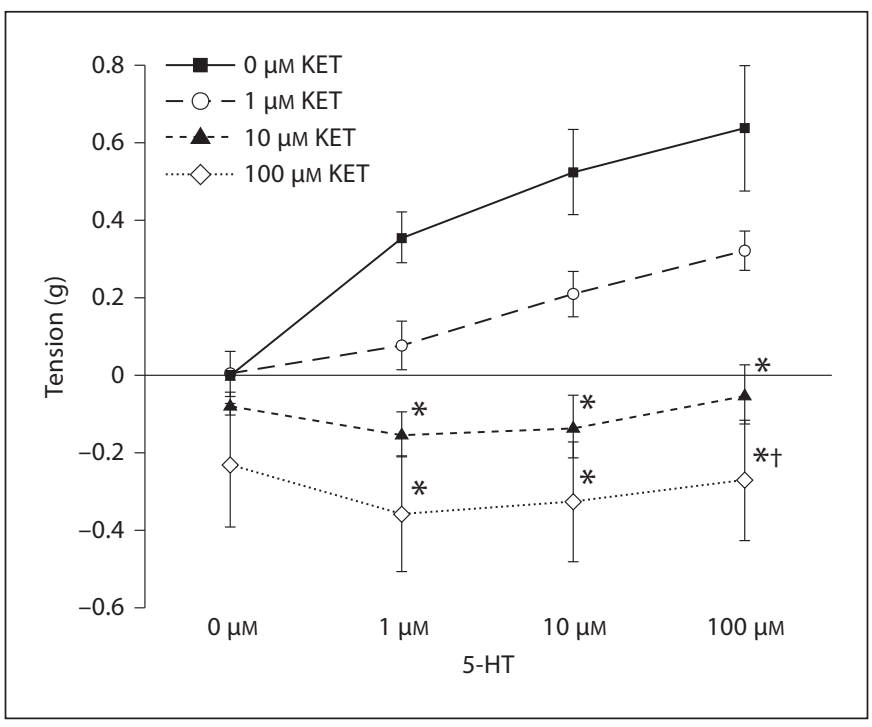

Fig. 6. Effect of preincubation with a $5-\mathrm{HT}_{2}$ receptor antagonist on 5-HT concentration response in the HDMA group; tension response to EFS. * Tension is significantly less than $0 \mu \mathrm{M} \mathrm{KET}$ at the same 5-HT concentration. ${ }^{+}$Tension is significantly less than $1 \mu \mathrm{M} \mathrm{KET}$ at the same 5-HT concentration. Values are means \pm $\mathrm{SE}, \mathrm{n}=6(\mathrm{p}<0.05)$. KET $=$ Ketanserin.

duced tension at $1 \mu \mathrm{M} 5$-HT (fig. 7a). In the $\mathrm{O}_{3}$ group, airway rings preincubated with $100 \mu \mathrm{M}$ ondansetron significantly attenuated the EFS response at all 5-HT concentrations compared to the control. At $1 \mu \mathrm{M}$ of $5-\mathrm{HT}$, tissue preincubated with $100 \mu \mathrm{M}$ ondansetron showed a significantly depressed EFS response when compared to the tissue preincubated with $10 \mu \mathrm{M}$ ondansetron. At 100 $\mu \mathrm{M}$ of $5-\mathrm{HT}$, tissue preincubated with $10 \mu \mathrm{M}$ ondansetron exhibited a significantly attenuated EFS response compared to the control curve (ondansetron effect, $\mathrm{p}<0.0001$ ) (fig. $7 b$ ). In the $\mathrm{HDMA}+\mathrm{O}_{3}$ group, tissue incubated with $100 \mu \mathrm{M}$ ondansetron significantly depressed tension response when compared to the control curve at 10 and 100 $\mu \mathrm{M}$ 5-HT (fig. 7c).

\section{GR 113808 (5- $\mathrm{HT}_{4}$ Receptor Antagonist)}

HDMA-exposed tissue incubated with 10 and $100 \mu \mathrm{M}$ GR 113808 significantly attenuated the EFS response at all 5-HT concentrations when compared to the control. Tissue preincubated with 1 and $10 \mu \mathrm{M}$ GR 113808 significantly reduced the EFS response compared to the control at 10 and $100 \mu \mathrm{M} 5$-HT (fig. 8a). In the $\mathrm{O}_{3}$ group, tissue incubated with $100 \mu \mathrm{M}$ GR 113808 produced significantly more tension than the control at $1 \mu \mathrm{M} 5-\mathrm{HT}$, but produced significantly less tension than the control at 10 and $100 \mu \mathrm{M} 5$-HT (fig. 8b). There was a significant concentration effect with all tested antagonists in the exposure groups selected on the basis of previous positive agonist responses (table 3 ).

\section{Direct Effect of 8-OH-DPAT}

Addition of $100 \mu \mathrm{M}$ of the $5-\mathrm{HT}_{1}$ receptor agonist, 8-OH-DPAT, attenuated tension induced via preincubation with $100 \mu \mathrm{M}$ exogenous $\mathrm{ACh}$, independent of the group. In all 4 groups, $100 \mu \mathrm{M}$ 8-OH-DPAT addition sig- 


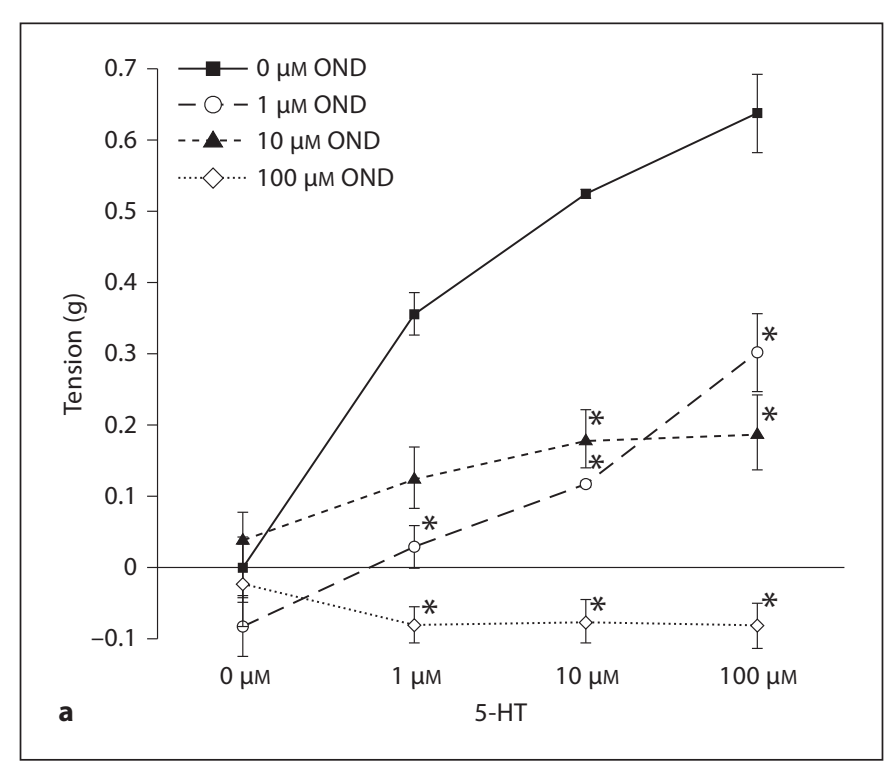

Fig. 7. Effect of preincubation with a $5-\mathrm{HT}_{3}$ receptor antagonist on 5-HT concentration response in the $\mathrm{HDMA}, \mathrm{O}_{3}$ and $\mathrm{HDMA}+\mathrm{O}_{3}$ groups; tension response to EFS. a HDMA group. b $\mathrm{O}_{3}$ group. c $\mathrm{HDMA}+\mathrm{O}_{3}$ group. ${ }^{*}$ Tension is significantly less than $0 \mu \mathrm{M}$ OND at the same 5 -HT concentration level. ${ }^{\dagger}$ Tension is significantly less than $10 \mu \mathrm{M}$ OND at the same 5-HT concentration. Values are means $\pm \mathrm{SE}, \mathrm{n}=6(\mathrm{p}=0.05)$. OND $=$ Ondansetron.

nificantly reduced the ACh-induced tension (\% change: $\mathrm{FA}=-45 \%$, $\mathrm{HDMA}=-52 \%, \mathrm{O}_{3}=-58 \%, \mathrm{HDMA}+\mathrm{O}_{3}=$ $-59 \%)$. The control tissue did not show a significant reduction in tension after $10 \mathrm{~min} .10 \mu \mathrm{M}$ 8-OH-DPAT did show a moderate attenuation in tension, but this decrease did not result in a significant reduction (FA; $\mathrm{p}=0.197$, HDMA; $\left.\mathrm{p}=0.258, \mathrm{O}_{3} ; \mathrm{p}=0.083, \mathrm{HMDA}+\mathrm{O}_{3}=0.095\right)$ (fig. 9).

\section{Concluding Investigations}

Tissue Viability

Each airway ring was contracted with exogenously applied $10 \mathrm{~mm}$ ACh. The tension produced by this applica-
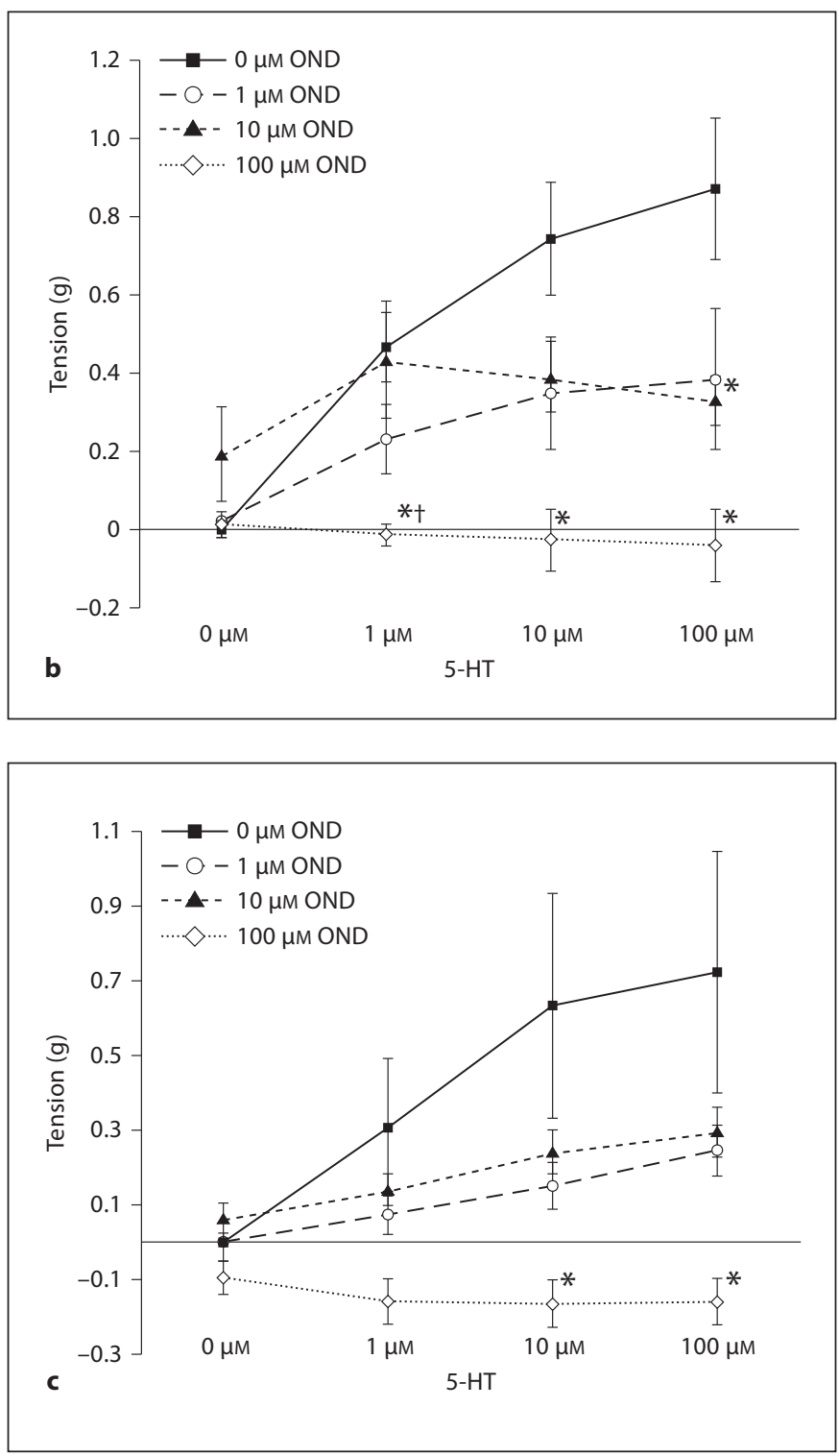

tion was compared to the maximum tension achieved during the ACh concentration-response curves conducted at the onset of the experiment. There was no significant difference between the responses of any of the tissue at the onset of the protocol compared to the responses at the conclusion. The average end tension response across all groups was $>87 \%$ of the initial response.

\section{Mechanism}

Incubation with atropine $(1 \mu \mathrm{M})$ or tetrodotoxin $(3 \mu \mathrm{M})$ blocked EFS-induced contraction, implying that tension produced by EFS is mediated through a cholinergic mechanism of neural origin. 

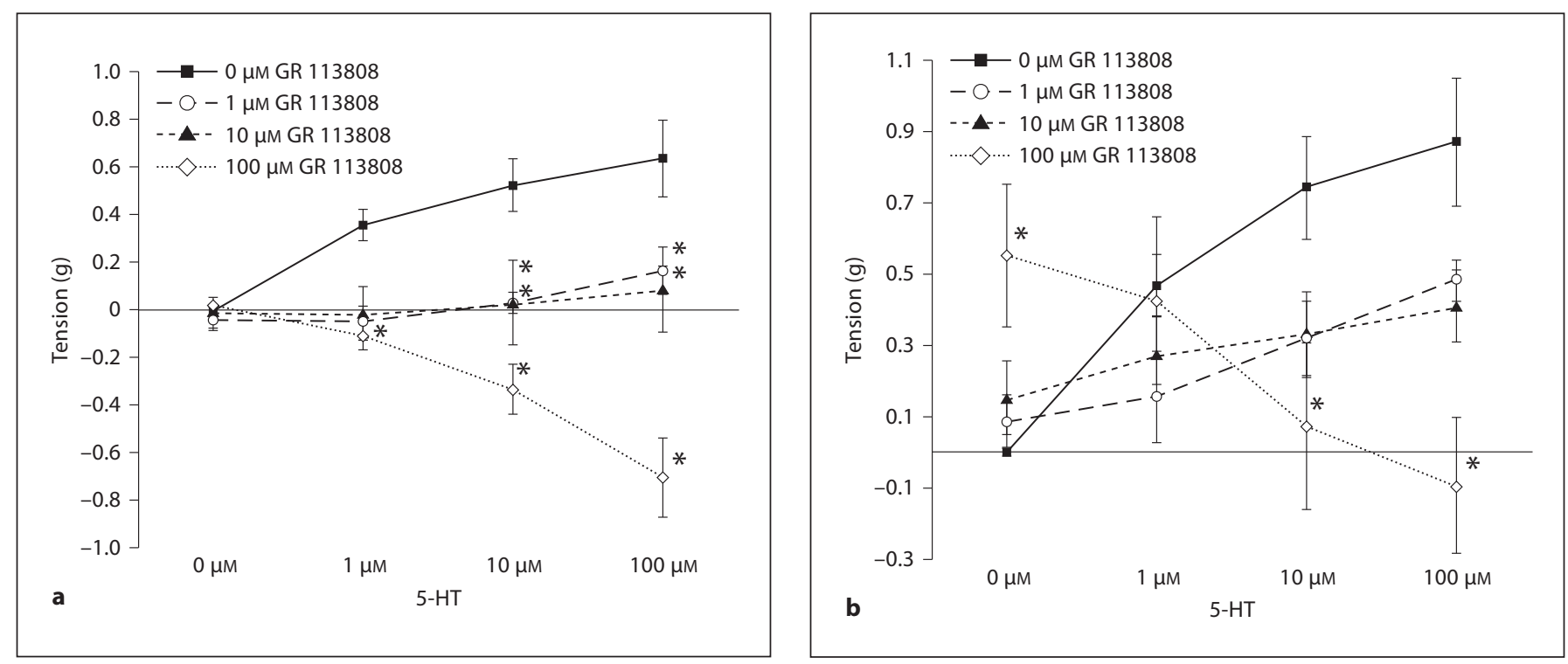

Fig. 8. Effect of preincubation with a $5-\mathrm{HT}_{4}$ receptor antagonist on 5 - $\mathrm{HT}$ concentration response in the $\mathrm{HDMA}$ and $\mathrm{O}_{3}$ groups. a HDMA group. $\mathbf{b} \mathrm{O}_{3}$ group. ${ }^{*}$ Tension is significantly different than $0 \mu \mathrm{M}$ GR 113808 . Values are means $\pm \mathrm{SE}, \mathrm{n}=6(\mathrm{p}=0.05)$.

Fig. 9. Effect of 8-OH-DPAT on precontracted tissue with $100 \mu \mathrm{M}$ ACh after a 10min (black column) incubation period (white column = at baseline). a FA group. b HDMA group. c $\mathrm{O}_{3}$ group. d $\mathrm{HDMA}+\mathrm{O}_{3}$ group. ${ }^{*}$ Tension is significantly lower than control. Values are means $\pm S E, n=6(p=$ 0.05).

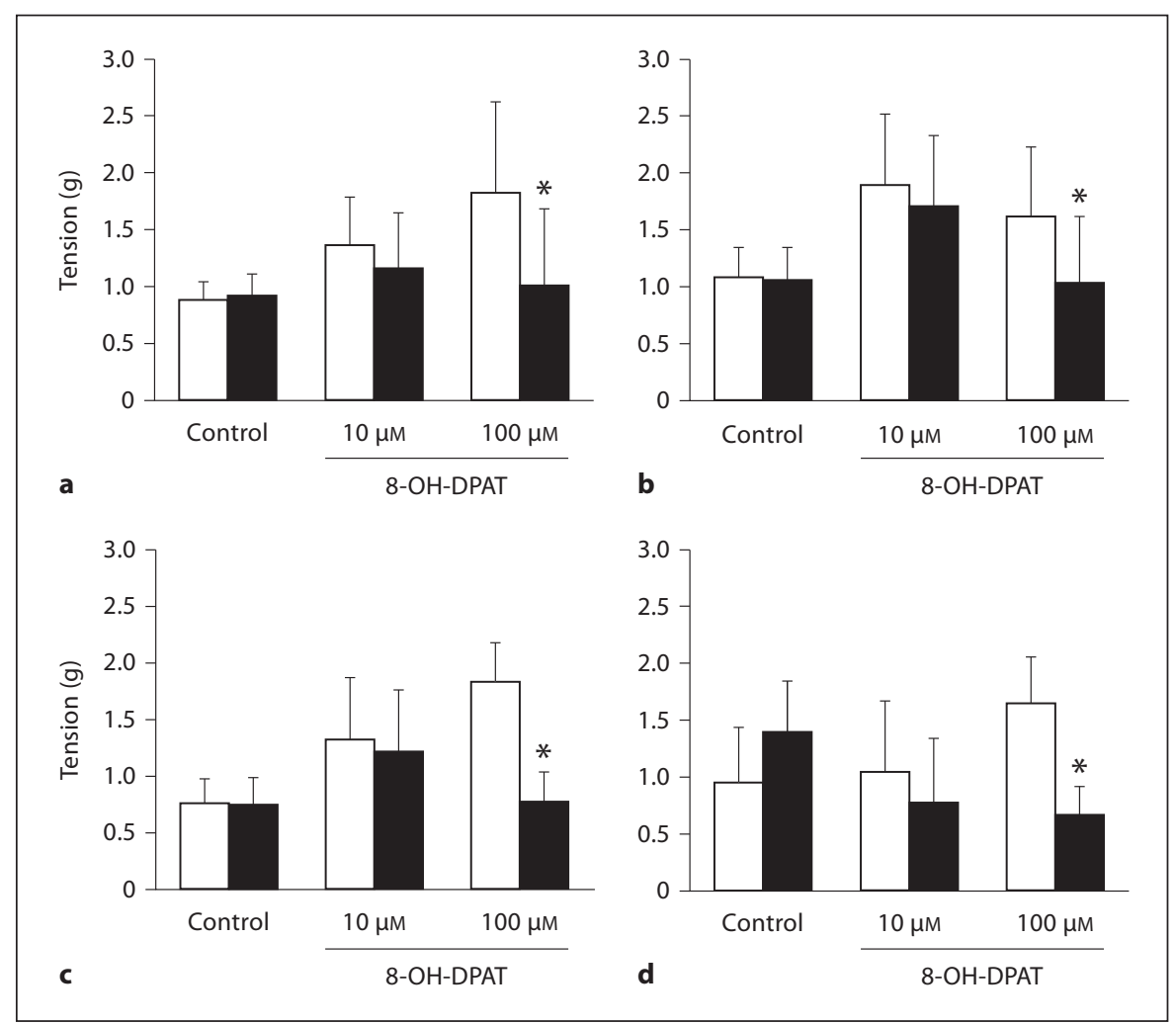




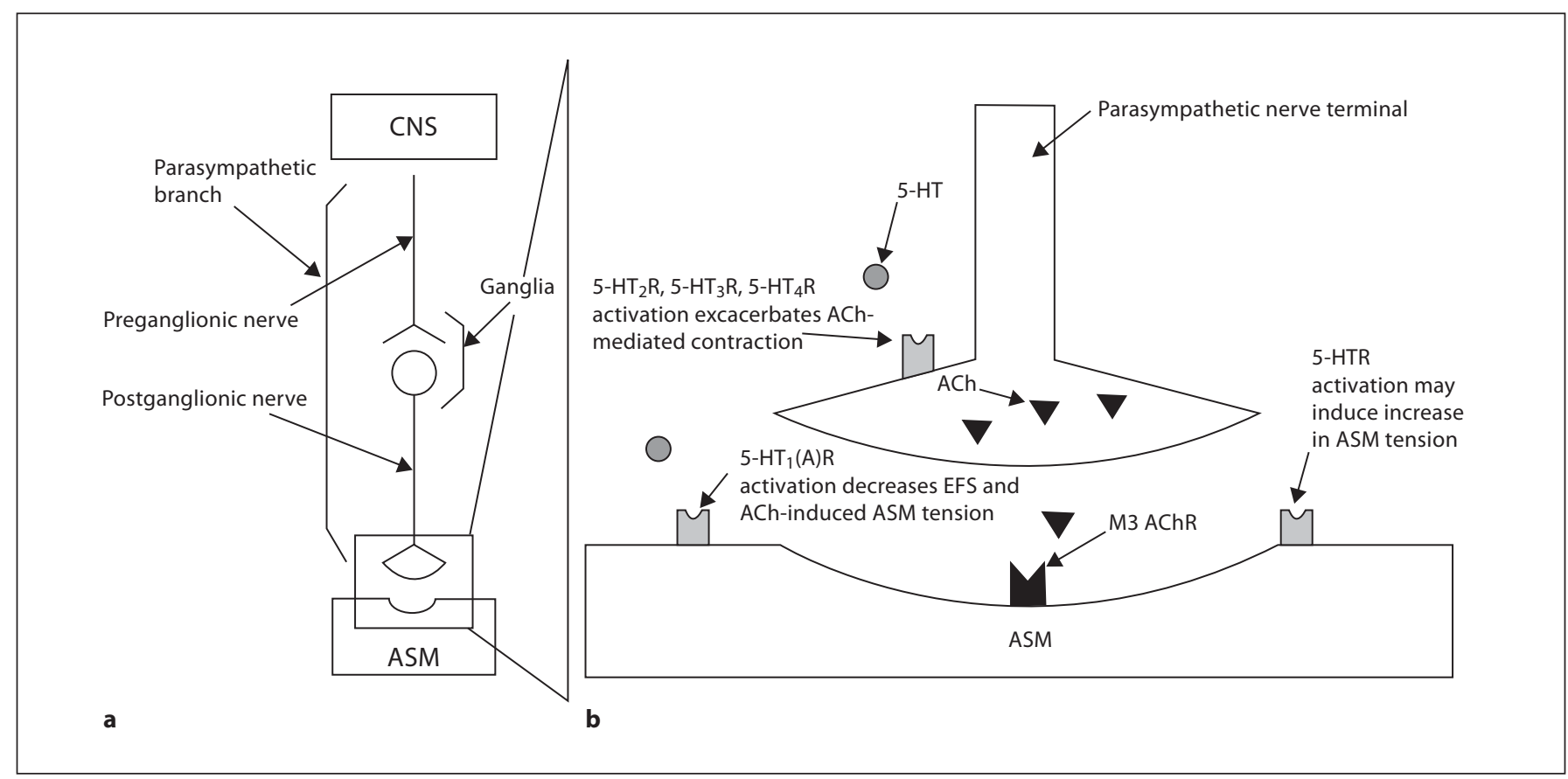

Fig. 10. Working model of parasympathetic ASM control. a Parasympathetic signaling pathway from CNS to AMS. b Exploded view of parasympathetic nerve terminal and neuromuscular junction highlighting the proposed sites of 5-HT's modulation of ASM contraction. Activation of 5-HT receptors on cholinergic nerve terminal enhances ACh release during parasympathetic ac- tivation. A specific $5-\mathrm{HT}_{1}$ receptor, possibly the $5-\mathrm{HT}_{1 \mathrm{~A}}$ subtype, located on ASM, induces muscle relaxation when activated. There is some evidence that 5-HT receptors located directly on ASM may cause an increase in ASM activity when activated. 5-HTR = Serotonin receptor; M3 = muscarinic receptor.

\section{Discussion}

This study shows that repeated exposure of allergic infant monkeys to $\mathrm{HDMA}, \mathrm{O}_{3}$ or $\mathrm{HDMA}+\mathrm{O}_{3}$ exacerbates cholinergic-mediated ASM response to EFS in the presence of exogenous 5-HT, a response that was not present in HDMA-sensitized FA control animals. Further evaluation with specific 5-HT subtype receptor agonists revealed that the activation of $5-\mathrm{HT}_{2}, 5-\mathrm{HT}_{3}$ and $5-\mathrm{HT}_{4}$ receptors contributes to the serotonergic exacerbation of EFS-induced ASM contraction in the HDMA group, while $5-\mathrm{HT}_{3}$ and $5-\mathrm{HT}_{4}$ receptors contribute to exacerbations in the $\mathrm{O}_{3}$ group, and $5-\mathrm{HT}_{3}$ receptors were solely responsible for the response in the $\mathrm{HDMA}+\mathrm{O}_{3}$ group. Antagonists for these 3 receptor subtypes attenuated the ASM response to 5-HT, further supporting that these receptors play a prominent role in the overall response to 5-HT. Conversely, a strong, consistent and reproducible inhibitory effect was documented in the FA control group as well as in the exposure groups, with the activation of $5-\mathrm{HT}_{1}$ receptors. Addition of the $5-\mathrm{HT}_{1}$ receptor agonist
8-OH-DPAT not only attenuated EFS-induced ASM contraction, but also relaxed ASM that had been precontracted with ACh. This indicates that the $5-\mathrm{HT}_{1}$ receptor's inhibitory effect is mediated through receptors located directly on ASM. When airway tissue was preincubated with 5-HT, the $\mathrm{EC}_{50}$ calculated from the ACh concentration-response curve significantly increased compared to the control curves across all groups (fig. 3). This supports the proposed $5-\mathrm{HT}_{1}$ receptor mechanism, indicating that 5-HT does exhibit some inhibitory effect directly on ASM, confirming previous work that documents the presence of a competing inhibitory 5-HT mechanism in ASM control $[19,23,33]$. Due to the implicated postsynaptic location of an inhibitory $5-\mathrm{HT}_{1}$ receptor, activation of this receptor is not dependent on parasympathetic signaling to exert its effect. These results indicate that in the airways of allergic monkeys there are competing 5-HT-mediated mechanisms; activation of 5-HT receptors residing on the cholinergic nerve terminal exacerbate the ASM response, while activation of a postsynaptic $5-\mathrm{HT}_{1}$ receptor located directly on the ASM inhibits contraction (fig. 10). 
We postulate that the exacerbated tension response seen in $\mathrm{HDMA}, \mathrm{O}_{3}$ and $\mathrm{HDMA}+\mathrm{O}_{3}$-exposed monkeys during EFS-induced ASM contraction is due to an enhancement of the excitatory mechanism, rather than a dysregulation of the inhibitory mechanism. An enhanced EFS response was only seen in the 3 exposure groups, and not in the FA control, but the direct inhibitory effect of the $5-\mathrm{HT}_{1}$ receptor agonist was seen across all 4 groups. The magnitude of the inhibitory response was not affected by exposure. This leads us to conclude that the exacerbated ASM contraction in exposed animals is due to enhanced ACh release from the terminal parasympathetic nerve via increased activation and/or upregulation of 5-HT receptors or their associated secondary messenger systems (fig. 10).

Interestingly, prior to 5-HT addition, there appeared to be no functional difference between FA controls and exposed animals when examining EFS-induced contractions or the intrinsic contractibility of the ASM (frequen$c y-$, voltage- and ACh concentration-response curves). In fact, during the ACh concentration-response curve, there was a significant increase in the $\mathrm{EC}_{50}$ of the $\mathrm{O}_{3}$ group compared to the other 2 exposure groups and the FA control, indicating a decrease in contractility of the $\mathrm{O}_{3}$-exposed animals. The decreased response of $\mathrm{O}_{3}$-exposed tissue to exogenous $\mathrm{ACh}$ is in accordance with the lack of airway hyperresponsiveness in the $\mathrm{O}_{3}$ group during the histamine challenge (fig. 2). Regardless of the reduced intrinsic contractibility of the ASM of the $\mathrm{O}_{3}$ group, this tissue still showed a significantly greater response to 5-HT during EFS-induced contractions in the presence of 5-HT (fig. 4). Based on the ex vivo ACh concentrationresponse curves and the EFS experiments, it appears that $\mathrm{O}_{3}$ exposure may lead to a decreased intrinsic contractibility of ASM, but the excitatory parasympathetic, cholinergic pathway is enhanced in the presence of 5-HT. When looking at the whole animal response in the $\mathrm{O}_{3}$ group based on the EC200R $\mathrm{R}_{\mathrm{aw}}$ derived from the histamine challenge, the inhibitory mechanism of reduced ASM contractility seems to overwhelm any exacerbated parasympathetic cholinergic response, resulting in airway responsiveness similar to that of the control group (fig. 2).

The histamine challenge performed at 6 months of age indicates that HDMA exposure does lead to development of a hyperreactive airway phenotype in the whole animal. Associated with the increase in airway reactivity, the HDMA group showed a significant response to all 3 excitatory 5-HT receptors examined in this study (fig. 5). Although $\mathrm{HDMA}+\mathrm{O}_{3}$ exposure did not result in a sig- nificant decrease in $\mathrm{EC}_{2} 00 \mathrm{R}_{\mathrm{aw}}$, there was a trend towards a more reactive airway, (fig. 2) and this trend was associated with an increased sensitivity of the $5-\mathrm{HT}_{3}$ receptor only. The small number of animals tested may have also made it more difficult to identify significant differences among groups in these in vivo and ex vivo studies, considering the intrinsic biological variability observed between individual animals.

Although this is the first time that serotonergic modulation of ASM has been evaluated in a model of asthma to date, there is substantial evidence in the literature that 5 -HT does play a role in ASM function. It is well documented that 5-HT functions as a modulator of neurotransmitter release at cholinergic nerves [17]. Multiple human tissue and animal studies show that 5-HT exacerbates cholinergic-mediated ASM contraction [20, 21, 34, $63,64]$. Clinical research in humans indicates that 5-HT contributes to AHR and lung function decrements that are seen in asthmatic populations, and that medications modifying serotonergic signaling improve asthma-related symptoms [19, 23, 32, 65-67].

It has also been substantiated that environmental exposures to HDMA and $\mathrm{O}_{3}$ exacerbate AHR and may lead to the development of asthma, although the exact mechanisms involved have yet to be elucidated $[7,8,11-13,15$, 16, 68-78]. Work by Kajekar et al. [13] has linked the early life exposure of nonhuman primates to $\mathrm{HDMA}, \mathrm{O}_{3}$ and $\mathrm{HDMA}+\mathrm{O}_{3}$ to an increase in serotonin-positive cells populating the airway epithelium. If exposure to HDMA and/or $\mathrm{O}_{3}$ leads to an increased presence of 5-HT or an increased sensitivity of the receptor mechanism in the airway, this could induce AHR and exacerbate asthma symptoms. The model employed in this study is ideal to evaluate the 5-HT-modulated EFS response to exposure due to the similar postnatal maturation processes of the human and rhesus monkey lung and the ability of our sensitization protocol to reproduce the characteristics of childhood allergic asthma.

Although a functional study of this nature using EFS and whole excised airway tissue allows an insight into the role of 5-HT in ASM function in a model of childhood allergic asthma, the limitations of such an experimental preparation must be acknowledged. By removing the trachea from its native environment, sectioning it into tissue rings and rinsing it repeatedly with a modified Kreb's solution, it is possible that endogenous 5-HT in the tissue was removed so that any hypersensitization of the terminal cholinergic nerve to 5-HT was not apparent until the addition of exogenous 5-HT. We attempted to employ the most selective agonists and antagonists available. Even 
so, due to the variance of published receptor affinities, a quantitative, rank-order comparison of the contributions of each receptor subtype to the 5-HT enhancement of ASM contraction could not be established. There is also the possibility of partial activation of multiple receptor subtypes by any one agonist, especially at higher concentrations. There is evidence that 5-HT may directly induce the contraction of smooth muscle [19, 20, 79]. When higher concentrations of 5-HT and some of the agonists were added, sporadic baseline shifts in tension were recorded. Any tissue that underwent a significant baseline shift after addition of a drug was excluded from EFS analysis. Because our focus was on neurally mediated ASM contraction, the direct effect of the enhancement by $5-\mathrm{HT}$ of ASM contraction in exposed allergic monkeys will be investigated in future projects. This study focused on a conducting airway site located in the middle-to-lower trachea. Previous research has shown that vascular remodeling in HDMA-exposed airways is generation-specific [80]. It is possible that $\mathrm{HDMA}, \mathrm{HDMA}+\mathrm{O}_{3}$ and $\mathrm{O}_{3}$ exposure may have a differential effect along segments of the tracheobronchial tree. Studies evaluating ASM function at alternate airway levels could assess whether exposure effects are widespread and consistent throughout conducting airways.

Further research coupling pulmonary function analysis, histological identification of 5-HT receptor subtypes at the parasympathetic ganglia, terminal cholinergic nerves and ASM coupled with ex vivo EFS experiments similar to the one described here would be of great value. Such experiments would allow researchers to compare the structure and function of HDMA-, $\mathrm{O}_{3^{-}}$and $\mathrm{HDMA}+\mathrm{O}_{3}$-exposed airways and the role of 5-HT in the asthmatic disease process. In addition, studies varying the onset of exposure during postnatal growth and development may shed light on how early these physiological changes take place and whether animals are more susceptible at different developmental ages.

Our study demonstrates that HDMA, $\mathrm{O}_{3}$ and $\mathrm{HDMA}+\mathrm{O}_{3}$ exposure in a model of childhood allergic asthma exacerbates EFS-induced ASM contraction through a 5-HT-mediated mechanism. There was no statistically different response between exposure groups. Further evaluation with agonists for specific 5-HT subtype receptors indicates that $5-\mathrm{HT}_{2}, 5-\mathrm{HT}_{3}$ and $5-\mathrm{HT}_{4}$ receptors can play a role in this response. A counterbalancing inhibitory effect was also uncovered, mediated via $5-\mathrm{HT}_{1}$ receptors. This inhibitory effect is transmitted through a receptor located directly on the ASM, rather than on the terminal cholinergic nerve. This study indicates that the increase in asthma symptoms and diagnosis among allergic childhood populations may be mediated in part through the dysregulation of 5-HT signaling at the postganglionic parasympathetic nerve, resulting in a hyperresponsive airway phenotype.

\section{References}

$>1$ Akinbami LJ, Moorman JE, Garbe PL, Sondik EJ: Status of childhood asthma in the United States, 1980-2007. Pediatrics 2009; 123(suppl 3):S131-S145.

2 Prevention CfDCa: National hospital discharge survey, 2000; in Branch HCS (ed): Scientific Data Documentation. Hyattsville, Centers for Disease Control and Prevention, 2000 .

3 Bloom B, Cohen RA, Freeman G: Summary Health Statistics for U.S. Children: national health interview survey, 2009. Vital Health Stat 2010;247:1-82.

$\checkmark 4$ Weiss KB, Sullivan SD: The health economics of asthma and rhinitis. I. Assessing the economic impact. J Allergy Clin Immunol 2001;107:3-8.

5 Platts-Mills TA: Dust mite allergens and asthma - a worldwide problem. J Allergy Clin Immunol 1989;83:416-427.
6 Hoshino M, Ohtawa J: Effects of adding omalizumab, an anti-immunoglobulin E antibody, on airway wall thickening in asthma. Respiration 2012;83:520-528.

7 Khatri SB, Holguin FC, Ryan PB, Mannino D, Erzurum SC, Teague WG: Association of ambient ozone exposure with airway inflammation and allergy in adults with asthma. J Asthma 2009;46:777-785.

8 McConnell R, Berhane K, Gilliland F, London SJ, Islam T, Gauderman WJ, Avol E, Margolis HG, Peters JM: Asthma in exercising children exposed to ozone: a cohort study. Lancet 2002;359:386-391.

9 State of the Air 2011. Washington, American Lung Association, 2011, pp 175.

10 Gauderman WJ, Avol E, Gilliland F, Vora $\mathrm{H}$, Thomas D, Berhane K, McConnell R, Kuenzli N, Lurmann F, Rappaport E, Margolis H, Bates D, Peters J: The effect of air pollution on lung development from 10 to 18 years of age. N Engl J Med 2004;351:10571067.
11 Plopper CG, Smiley-Jewell SM, Miller LA, Fanucchi MV, Evans MJ, Buckpitt AR, Avdalovic M, Gershwin LJ, Joad JP, Kajekar R, Larson S, Pinkerton KE, Van Winkle LS, Schelegle ES, Pieczarka EM, Wu R, Hyde DM: Asthma/allergic airways disease: does postnatal exposure to environmental toxicants promote airway pathobiology? Toxicol Pathol 2007;35:97-110.

12 Schelegle ES, Miller LA, Gershwin LJ, Fanucchi MV, Van Winkle LS, Gerriets JE, Walby WF, Mitchell V, Tarkington BK, Wong VJ, Baker GL, Pantle LM, Joad JP, Pinkerton KE, Wu R, Evans MJ, Hyde DM, Plopper CG: Repeated episodes of ozone inhalation amplifies the effects of allergen sensitization and inhalation on airway immune and structural development in rhesus monkeys. Toxicol Appl Pharmacol 2003;191:74-85. 
13 Kajekar R, Pieczarka EM, Smiley-Jewell SM, 26 Abdullah NA, Hirata M, Matsumoto K, Schelegle ES, Fanucchi MV, Plopper CG: Early postnatal exposure to allergen and ozone leads to hyperinnervation of the pulmonary epithelium. Respir Physiol Neurobiol 2007;155:55-63.

14 Larson SD, Schelegle ES, Walby WF, Gershwin LJ, Fanuccihi MV, Evans MJ, Joad JP, Tarkington BK, Hyde DM, Plopper CG: Postnatal remodeling of the neural components of the epithelial-mesenchymal trophic unit in the proximal airways of infant rhesus monkeys exposed to ozone and allergen. Toxicol Appl Pharmacol 2004;194:211-220.

- 15 Evans MJ, Fanucchi MV, Baker GL, Van Winkle LS, Pantle LM, Nishio SJ, Schelegle ES, Gershwin LJ, Miller LA, Hyde DM, Sannes PL, Plopper CG: Atypical development of the tracheal basement membrane zone of infant rhesus monkeys exposed to ozone and allergen. Am J Physiol Lung Cell Mol Physiol 2003;285:L931-L939.

- 16 Evans MJ, Fanucchi MV, Baker GL, Van Winkle LS, Pantle LM, Nishio SJ, Schelegle ES, Gershwin LJ, Miller LA, Hyde DM, Plopper CG: The remodelled tracheal basement membrane zone of infant rhesus monkeys after 6 months of recovery. Clin Exp Allergy 2004;34:1131-1136.

17 Fink KB, Gothert M: 5-HT receptor regulation of neurotransmitter release. Pharmacol Rev 2007;59:360-417.

$\checkmark 18$ Davenport TE, Stevens SR, Baroni K, Van Ness M, Snell CR: Diagnostic accuracy of symptoms characterising chronic fatigue syndrome. Disabil Rehabil 2011;33:17681775.

19 Cazzola I, Matera MG: 5-HT modifiers as a potential treatment of asthma. Trends Pharmacol Sci 2000;21:13-16.

-20 Takahashi T, Ward JK, Tadjkarimi S, Yacoub MH, Barnes PJ, Belvisi MG: 5-hydroxytryptamine facilitates cholinergic bronchoconstriction in human and guinea pig airways. Am J Respir Crit Care Med 1995; 152:377380.

21 Szarek JL, Zhang JZ, Gruetter CA: Mechanisms of 5-hydroxytryptamine-induced contraction of isolated rat intrapulmonary bronchi. Pulm Pharmacol 1995;8:273-281.

22 Dupont L, Pype J, Demedts M, De Leyn P, Deneffe G, Verleden G: The effects of 5-HT on cholinergic contraction in human airways in vitro. Eur Respir J 1999;14:642-649.

23 Cazzola M, Matera MG, D’Amato G, Rossi F: Effects of serotonin on airways: recent developments. Allergy 1995;50:1-10.

-24 Aizawa H, Takata S, Shigyo M, Matsumoto $\mathrm{K}$, Inoue $\mathrm{H}$, Hara N: N-omega-nitro-L-arginine methyl ester increases airway responsiveness to serotonin but not to acetylcholine in cats in vivo. Respiration 2001;68:286-291.

25 Yoshida M, Aizawa H, Hara N: Effect of endothelin-1 on the serotonin-induced contraction of smooth muscle in the guinea pig trachea. Respiration 1999;66:59-64.
Aizawa $\mathrm{H}$, Inoue $\mathrm{R}$, Hamano S, Ikeda S, Xie Z, Hara N, Ito Y: Contraction and depolarization induced by fetal bovine serum in airway smooth muscle. Am J Physiol 1994; 266:L528-L535.

27 Albu G, Petak F, Fontao F, Biton C, Pache JC, Habre W: Mechanisms of airway hyper-responsiveness after coronary ischemia. Respir Physiol Neurobiol 2008;162:176-183.

28 Almirall JJ, Dolman CS, Eidelman DH: Furosemide-induced bronchodilation in the rat bronchus: evidence of a role for prostaglandins. Lung 1997;175:155-163.

29 Atzori L, Bannenberg G, Corriga AM, Congiu L, Lundberg JM, Moldeus P, Ryrfeldt A: Sodium metabisulfite and citric acid induce bronchoconstriction via a sulfite-sensitive pathway in the isolated guinea pig lung. Respiration 1997;64:145-151.

30 Lechin F, van der Dijs B, Orozco B, Lechin $\mathrm{M}$, Lechin AE: Increased levels of free serotonin in plasma of symptomatic asthmatic patients. Ann Allergy Asthma Immunol 1996;77:245-253.

31 Lechin F, van der Dijs B, Lechin A, Orozco B, Lechin M, Baez S, Rada I, Leon G, Acosta E: Plasma neurotransmitters and cortisol in chronic illness: role of stress. J Med 1994;25: 181-192.

32 Lechin F, van der Dijs B, Orozco B, Jara H, Rada I, Lechin ME, Lechin AE: Neuropharmacologic treatment of bronchial asthma with the antidepressant tianeptine: a doubleblind, crossover placebo-controlled study. Clin Pharmacol Ther 1998;64:223-232.

-33 Dupont LJ, Pype JL, Demedts MG, De Leyn P, Deneffe G, Verleden GM: The effects of 8-hydroxy-2-(di-n-propylamino)tetralin on the cholinergic contraction in guinea pig and human airways in vitro. Am J Respir Crit Care Med 1998;158:1479-1486.

34 Dupont L, Pype J, Meade C, DeLeyn P, Deneffe G, Demedts M, Verleden G: Epinastine (WAL 801CL) inhibits the electrical field stimulation-induced cholinergic contraction in guinea pig and human airways in vitro. Eur Respir J 1999;14:1068-1075.

35 Evans MJ, Fanucchi MV, Plopper CG, Hyde DM: Postnatal development of the lamina reticularis in primate airways. Anat Rec 2010; 293:947-954.

36 Plopper CG, Heidsiek JG, Weir AJ, George JA, Hyde DM: Tracheobronchial epithelium in the adult rhesus monkey: a quantitative histochemical and ultrastructural study. Am J Anat 1989;184:31-40.

37 Plopper CG, Alley JL, Weir AJ: Differentiation of tracheal epithelium during fetal lung maturation in the rhesus monkey Macaca mulatta. Am J Anat 1986;175:59-71.

38 Plopper C, St George J, Cardoso W, Wu R, Pinkerton K, Buckpitt A: Development of airway epithelium. Patterns of expression for markers of differentiation. Chest 1992;101: $2 S-5 S$.
39 Plopper CG, Weir AJ, Nishio SJ, Cranz DL, St George JA: Tracheal submucosal gland development in the rhesus monkey, Macaca mulatta: ultrastructure and histochemistry. Anat Embryol 1986;174:167-178.

40 Miller LA, Plopper CG, Hyde DM, Gerriets JE, Pieczarka EM, Tyler NK, Evans MJ, Gershwin LJ, Schelegle ES, Van Winkle LS: Immune and airway effects of house dust mite aeroallergen exposures during postnatal development of the infant rhesus monkey. Clin Exp Allergy 2003;33:1686-1694.

41 Schelegle ES, Gershwin LJ, Miller LAC, Fanucchi MV, Van Winkle LS, Gerriets JP, Walby WF, Omlor AM, Buckpitt AR, Tarkington BK, Wong VJ, Joad JP, Pinkerton KB, Wu R, Evans MJ, Hyde DM, Plopper CG: Allergic asthma induced in rhesus monkeys by house dust mite (Dermatophagoides farinae). Am J Pathol 2001;158:333-341.

42 National Research Council (US) Committee for the Update of the Guide for the Care and Use of Laboratory Animals: Guide for the Care and Use of Laboratory Animals, ed 8. Washington, National Academies Press, 2011.

43 Wilson DW, Plopper CG, Dungworth DL: The response of the macaque tracheobronchial epithelium to acute ozone injury. A quantitative ultrastructural and autoradiographic study. Am J Pathol 1984;116:193206.

44 Arvidsson LE, Hacksell U, Nilsson JL, Hjorth S, Carlsson A, Lindberg P, Sanchez D, Wikstrom H: 8-hydroxy-2-(di-n-propylamino)tetralin, a new centrally acting 5-hydroxytryptamine receptor agonist. J Med Chem 1981;24:921-923.

45 Middlemiss DN, Fozard JR: 8-hydroxy-2(di-n-propylamino)-tetralin discriminates between subtypes of the 5-HT1 recognition site. Eur J Pharmacol 1983;90:151-153.

46 Peroutka SJ: Pharmacological differentiation and characterization of $5-\mathrm{HT} 1 \mathrm{~A}$, 5-HT1B, and 5-HT1C binding sites in rat frontal cortex. J Neurochem 1986;47:529540.

47 Leung GP, Dun SL, Dun NJ, Wong PY: Serotonin via $5-\mathrm{HT} 1 \mathrm{~B}$ and $5-\mathrm{HT} 2 \mathrm{~B}$ receptors stimulates anion secretion in the rat epididymal epithelium. J Physiol 1999;519:657-667.

-48 Feldman PD: Effects of serotonin-1 and serotonin-2 receptor agonists on neuronal activity in the nucleus tractus solitarius. J Auton Nerv Syst 1995;56:119-124.

-49 Ismaiel AM, Titeler M, Miller KJ, Smith TS, Glennon RA: 5-HT1 and 5-HT2 binding profiles of the serotonergic agents alphamethylserotonin and 2-methylserotonin. J Med Chem 1990;33:755-758.

50 Wilson H, Coffman WJ, Cohen ML: 5-hydroxytryptamine 3 receptors mediate tachycardia in conscious instrumented dogs. J Pharmacol Exp Ther 1990;252:683-688. 
-51 Craig DA, Eglen RM, Walsh LK, Perkins LA, Whiting RL, Clarke DE: 5-methoxytryptamine and 2-methyl-5-hydroxytryptamineinduced desensitization as a discriminative tool for the 5-HT3 and putative 5-HT4 receptors in guinea pig ileum. Naunyn Schmiedebergs Arch Pharmacol 1990;342:9-16.

-52 Glennon RA, Lee M, Rangisetty JB, Dukat M, Roth BL, Savage JE, McBride A, Rauser L, Hufeisen S, Lee DK: 2-substituted tryptamines: agents with selectivity for 5-HT(6) serotonin receptors. J Med Chem 2000;43: 1011-1018.

53 Yang D, Soulier JL, Sicsic S, Mathe-Allainmat $\mathrm{M}$, Bremont B, Croci T, Cardamone R, Aureggi G, Langlois M: New esters of 4-amino-5-chloro-2-methoxybenzoic acid as potent agonists and antagonists for 5-HT4 receptors. J Med Chem 1997;40:608-621.

54 De Ponti F, Crema F, Moro E, Nardelli G, Croci T, Frigo GM: Intestinal motor stimulation by the 5 -HT4 receptor agonist ml10302: differential involvement of tachykininergic pathways in the canine small bowel and colon. Neurogastroenterol Motil 2001;13:543553.

-55 Soulier JL, Russo O, Giner M, Rivail L, Berthouze M, Ongeri S, Maigret B, Fischmeister R, Lezoualc'h F, Sicsic S, Berque-Bestel I: Design and synthesis of specific probes for human 5-HT4 receptor dimerization studies. J Med Chem 2005;48:6220-6228.

- 56 Frishman WH, Grewall P: Serotonin and the heart. Ann Med 2000;32:195-209.

- 57 Ju JM, Hwang JH, Piao LH, Park HW, Park JS, Shin DH, Cho JG, Kim KK, Kim JH: Ketanserin, a 5-HT2 antagonist, directly inhibits the ATP-sensitive potassium channel in mouse ventricular myocytes. J Cardiovasc Pharmacol 2006;47:96-102.

-58 Ye JH, Ponnudurai R, Schaefer R: Ondansetron: A selective 5-HT(3) receptor antagonist and its applications in CNS-related disorders. CNS Drug Rev 2001;7:199-213.

59 Youssefyeh RD, Campbell HF, Klein S, Airey JE, Darkes P, Powers M, Schnapper M, Neuenschwander K, Fitzpatrick LR, Pendley $\mathrm{CE}$, et al: Development of high-affinity 5-HT3 receptor antagonists. 1. Initial structure-activity relationship of novel benzamides. J Med Chem 1992;35:895-903.
60 Tuladhar BR, Costall B, Naylor RJ: Modulation of 5-HT4 receptor function in the rat isolated ileum by fluoxetine: the involvement of endogenous 5-hydroxytryptamine. Br J Pharmacol 2002;136:150-156.

61 Pindon A, van Hecke G, van Gompel P, Lesage AS, Leysen JE, Jurzak M: Differences in signal transduction of two 5-HT4 receptor splice variants: compound specificity and dual coupling with galphas- and galphai/ o-proteins. Mol Pharmacol 2002;61:85-96.

62 Gale JD, Grossman CJ, Whitehead JW, Oxford AW, Bunce KT, Humphrey PP: Gr113808: a novel, selective antagonist with high affinity at the 5-HT4 receptor. Br J Pharmacol 1994;111:332-338.

63 Matera MG, De Santis D, D’Agostino B, Pallotta M, Vacca C, Cazzola M, Rossi F: Role of 5-hydroxytryptamine in mediating adenosine-induced airway contraction. Immunopharmacology 1995;29:73-78.

64 Rizzo CA, Kreutner W, Chapman RW: 5-HT3 receptors augment neuronal, cholinergic contractions in guinea pig trachea. Eur J Pharmacol 1993;234:109-112.

65 Cazzola M, D’Amato G, Lobefalo G, Guillaro B, Sepe J, Assogna G, Pietroletti R, Lauria D: Ketanserin, a new blocking agent of serotonin S2-receptors. Respiratory functional effects in chronic obstruction of the airways. Chest 1987;92:863-866.

66 Lechin F, van der Dijs B, Lechin AE: Treatment of bronchial asthma with tianeptine. Methods Find Exp Clin Pharmacol 2004;26: 697-701.

67 Lechin F, van der Dijs B, Lechin AE: Tianeptine: a new exploratory therapy for asthma. Chest 2004;125:348-349.

68 Bateson TF, Schwartz J: Children's response to air pollutants. J Toxicol Environ Health A 2008;71:238-243.

69 House-dust mite allergen and asthma. N Engl J Med 1991;324:337-338.

70 Bertelsen RJ, Carlsen KC, Carlsen KH, Granum B, Doekes G, Haland G, Mowinckel P, Lovik M: Childhood asthma and early life exposure to indoor allergens, endotoxin and beta(1,3)-glucans. Clin Exp Allergy;40:307316.
71 Brookes KA, Adams WC, Schelegle ES: O.35 ppm $\mathrm{O} 3$ exposure induces hyperresponsiveness on 24 -h reexposure to $0.20 \mathrm{ppm} \mathrm{O3}$. J Appl Physiol 1989;66:2756-2762.

-72 Fanucchi MV, Plopper CG, Evans MJ, Hyde DM, Van Winkle LS, Gershwin LJ, Schelegle ES: Cyclic exposure to ozone alters distal airway development in infant rhesus monkeys. Am J Physiol Lung Cell Mol Physiol 2006; 291:L644-L650.

73 Gent JF, Triche EW, Holford TR, Belanger K, Bracken MB, Beckett WS, Leaderer BP: Association of low-level ozone and fine particles with respiratory symptoms in children with asthma. JAMA 2003;290:1859-1867.

74 Joad JP, Kott KS, Bric JM, Peake JL, Plopper CG, Schelegle ES, Gershwin LJ, Pinkerton KE: Structural and functional localization of airway effects from episodic exposure of infant monkeys to allergen and/or ozone. Toxicol Appl Pharmacol 2006;214:237-243.

75 Koren HS: Associations between criteria air pollutants and asthma. Environ Health Perspect 1995;103 Suppl 6:235-242.

76 Moore K, Neugebauer R, Lurmann F, Hall J, Brajer V, Alcorn S, Tager I: Ambient ozone concentrations cause increased hospitalizations for asthma in children: an 18-year study in southern California. Environ Health Perspect 2008;116:1063-1070.

-77 Schelegle ES, Adams WC, Giri SN, Siefkin $\mathrm{AD}$ : Acute ozone exposure increases plasma prostaglandin $\mathrm{f} 2$ alpha in ozone-sensitive human subjects. Am Rev Respir Dis 1989; 140:211-216.

78 Schelegle ES, Adams WC: Reduced exercise time in competitive simulations consequent to low level ozone exposure. Med Sci Sports Exerc 1986;18:408-414.

79 Moura CT, Bezerra FC, de Moraes IM, Magalhaes PJ, Capaz FR: Increased responsiveness to 5-hydroxytryptamine after antigenic challenge is inhibited by nifedipine and niflumic acid in rat trachea in vitro. Clin Exp Pharmacol Physiol 2005;32:1119-1123.

80 Avdalovic MV, Putney LF, Schelegle ES, Miller L, Usachenko JL, Tyler NK, Plopper CG, Gershwin LJ, Hyde DM: Vascular remodeling is airway generation-specific in a primate model of chronic asthma. Am J Respir Crit Care Med 2006;174:1069-1076. 